\title{
Pengaruh Pupuk N, P, K dan Pupuk Nano Silika Terhadap N-total, Serapan N dan Hasil Padi Hitam (Oryza sativa L. indica) pada Inceptisols
}

\author{
Anni Yuniarti1), Islamy Hasan Hermawan1), Rija Sudirja1) dan Dirga Sapta Sara1)
}

Departemen Ilmu Tanah dan Sumberdaya Lahan, Fakultas Pertanian Universitas Padjadjaran

Jl. Raya Bandung - Sumedang KM 21 Jatinangor, Sumedang

Korespondensi: islamyhh@gmail.com

\begin{abstract}
The Inceptisols have the potential to be developed into rice cultivation land because it is widely distributed in Indonesia but it has a low of soil fertility. Fertilization of $N, P, K$ and Nano Silica fertilizers are efforts to provide nutrients for rice plants. Black rice that functional cultivated is Bangir Lokal Cianjur Variety. This study aims to determine the effect of $N, P, K$ and Nano Silica fertilizes on total $N$ content, $N$ uptake, and Black Rice Yield (Oryza sativa L. indica) on Inceptisols. This research was conducted in November 2020 until March 2021 at the Soil Chemistry and Plant Nutrition Experimental Field, Faculty of Agriculture, Universitas Padjadjaran: Jatinangor with altitude $723 \mathrm{~m}$ asl. The experimental design was carried out using a RBD consisting of eight treatments and four replications. The treatments consisted of control (without fertilizers); $1 \mathrm{~N}, P, K$ (Urea $300 \mathrm{~kg} / \mathrm{ha}, S P-3650 \mathrm{~kg} / \mathrm{ha}$, and $\mathrm{KCl} 50 \mathrm{~kg} / \mathrm{ha}$ );1 N, $P, K+1$ Nano Silica $(2 \mathrm{~mL} / \mathrm{L}) ; 1 \mathrm{~N}, P, K+1,5$ Nano Silica $(3 \mathrm{~mL} / \mathrm{L}) ; 1 \mathrm{~N}, P, K+2$ Nano Silica $(4 \mathrm{~mL} / L) ; 3 / 4 \mathrm{~N}, P, K$ (Urea $225 \mathrm{~kg} / \mathrm{ha}, S P-3637,5 \mathrm{~kg} / \mathrm{ha}$, and $\mathrm{KCl} 37,5 \mathrm{~kg} / \mathrm{ha}$ ) + 1 Nano Silica; $3 / 4 \mathrm{~N}, P, K+1,5$ Nano Silica; $3 / 4 \mathrm{~N}, P$, $K+2$ Nano Silca. The result showed that the combination of fertilizers doses of $1 \mathrm{~N}, P, K$ and 1 Nano Silica gives the best black rice yield with Dry Grain weight of 77,8 $\mathrm{g} /$ clump of rice.
\end{abstract}

Keywords: black rice, dry land, nano silica fertilizer, nitrogen

\section{PENDAHULUAN}

Seiring dengan meingkatnya pengetahuan dan kesadaran masyarakat mengenai konsumsi beras yang bermanfaat bagi kesehatan, maka konsumsi beras hitam makin berkembang di Indonesia (Sudarwati, 2018). Beras hitam dikategorikan sebagai komoditas tanaman pangan fungsional yang perlu dikembangkan karena mengandung antosianin, kadar gula rendah, serat tinggi dan rasa yang lebih pulen (Dewi, dkk, 2017). Kandungan antosianin pada beras hitam dapat berfungsi sebagai antioksidan dan penangkal radikal bebas yang berpengaruh positif terhadap kesehatan (Suardi dan Ridwan, 2009).

Peningkatan produktivitas tanaman padi tidak terlepas dari upaya pemupukan. Pemupukan N, P, K sangat penting untuk menyediakan unsur hara makro primer bagi tanaman padi. Unsur N (nitrogen) diperlukan dalam jumlah yang paling banyak, karena berfungsi untuk menyusun protein sehingga mempercepat tumbuh tanaman. Pemberian pupuk $\mathrm{N}$ berpengaruh terhadap $\mathrm{N}$ total dan serapan $\mathrm{N}$ yang berkaitan dengan proses fotosintesis dan peningkatan produksi gabah Marzuki dkk. (2014) menyatakan bahwa pemberian pupuk urea $300 \mathrm{~kg} / \mathrm{ha}$ dapat memenuhi ketersediaan hara bagi tanaman sehingga menghasilkan jumlah anakan dan jumlah cabang malai yang lebih tinggi, serta produksi gabah kering giling yang tertinggi.

Upaya pemupukan lain adalah dengan penambahan unsur hara mikro esensial untuk memperbaiki kualitas hasil tanaman. Pemupukan unsur hara mikro belum banyak dilakukan pada lahan pertanian di Indonesia (Hayati dkk, 2019), padahal tanaman serealia membutuhkan unsur Si (silika) dalam jumlah yang cukup banyak (Subiksa, 2018). Pengaruh pemberian pupuk silika berperan dalam perbaikan tanah dan dapat meningkatkan kualitas tanaman. Hasil penelitian Kristanto (2018) menunjukkan pemupukan silika meningkatkan ketersediaan hara lain seperti $\mathrm{N}$, $\mathrm{P}, \mathrm{K}, \mathrm{dan} \mathrm{Si}$, kapasitas memegang air, KTK tanah serta meningkatkan kestabilan membran sel akar. 
Saat ini pupuk mikro telah tersedia dalam bentuk nano partikel. Pupuk silika berbentuk nano, atau dikenal dengan Nano Silika mulai dikembangkan di Indonesia. Penggunaan Si berukuran nano $\left(10^{-9} \mathrm{~m}\right)$ dapat meningkatkan kemampuan akar ataupun daun untuk menyerap unsur Si (Amrullah dkk, 2014). Pemberian Pupuk Nano Silika dapat menyediakan Si dalam komponen dinding sel tanaman yang dapat meningkat resistensi tanaman terhadap faktor abiotik (Greger, et al. 2018). Silika dengan ukuran nano dapat mengurangi transpirasi yang menyebabkan tanaman lebih rentan terhadap cekaman kekeringan, suhu, dan kelembaban (Al-Khuzai dan Al-Juthery, 2020; Greger, et al. 2018).

Pemberian pupuk N, P, K dan Nano Silika berperan untuk meningkatkan kesuburan tanah, terutama pada lahan suboptimal. Hasil penelitian Amalya (2020) menyatakan bahwa kombinasi dosis pupuk $1 \mathrm{~N}, \mathrm{P}, \mathrm{K}$ (300 kg Urea, $50 \mathrm{~kg}$ SP-36, dan $50 \mathrm{~kg} \mathrm{KCl} \mathrm{per} \mathrm{hektar)} \mathrm{+} 1$ Nano Silika ( $2 \mathrm{~mL} / \mathrm{L})$ untuk tanaman padi hitam pada tanah Inceptisols yang disawahkan. Aplikasi dosis pupuk tersebut juga memberikan pengaruh terbaik terhadap serapan $\mathrm{N}$ dan gabah kering giling.

Tujuan penelitian adalah mengetahui pengaruh dan kombinasi terbaik dosis pupuk N, P, K dan pupuk Nano Silika terhadap N total, serapan $\mathrm{N}$ dan hasil padi hitam (Oryza sativa $\mathrm{L}$. indica) pada Inceptisols. Berdasarkan permasalahan tersebut, maka perlu dilakukan penelitian mengenai aplikasi pupuk N, P, K dan Nano Silika terhadap produksi padi hitam yang dibudidayakan pada kondisi kering (padi gogo).

\section{METODOLOGI}

\subsection{Waktu dan Tempat Penelitian}

Penelitian ini dilaksanakan dari bulan November 2020 sampai dengan Maret 2021 di Kebun Percobaan Laboratorium Kimia Tanah dan Nutrisi Tanaman Fakultas Pertanian Universitas Padjadjaran, Jatinangor,
Kabupaten Sumedang. Ketinggian tempat berkisar $\pm 723 \mathrm{~m} \mathrm{dpl}$. Analisis kimia tanah dan tanaman dilaksanakan di Laboratorium Kimia Tanah dan Nutrisi Tanaman, Fakultas Pertanian Universitas Padjadjaran.

\subsection{Bahan dan Alat}

Bahan yang digunakan dalam penelitian ini dibedakan menjadi benih padi, media tanam, pupuk, dan bahan kimia. Benih padi hitam (Oryza sativa L. indica) yang digunakan adalah Varietas Bangir Lokal Cianjur. Media tanam yang digunakan berupa campuran dari tanah yang dikeringanginkan dan pupuk organik (kompos jerami padi, daun bambu, dedak, kotoran sapi).

Pupuk Nano Silika yang digunakan adalah pupuk cair nanosilika (Biomax) dengan kadar $\mathrm{SiO}_{2} 19,90 \%$. Pupuk anorganik yang digunakan meliputi Urea (46\%), SP-36 (36\% $\left.\mathrm{P}_{2} \mathrm{O}_{5}\right)$, dan $\mathrm{KCl}\left(50 \% \mathrm{~K}_{2} \mathrm{O}\right)$. Bahan-bahan kimia digunakan untuk analisis tanah dan tanaman ( $\mathrm{N}$-total dan serapan N). Alat yang digunakan meliputi alat penanaman, pengukuran, dokumentasi, serta software SPSS untuk pengolahan data.

\subsection{Rancangan Penelitian}

Rancangan penelitian menggunakan Rancangan Acak Kelompok (RAK) faktor tunggal yang terdiri dari delapan (8) perlakuan dengan empat (4) kali ulangan. Total unit yang digunakan pada percobaan ini sebanyak dua (2) unit. Unit pertama untuk pengambilan sampel vegetatif maksimum sedangkan unit kedua untuk komponen hasil, sehingga total keseluruhan terdapat 48 plot percobaan. Perlakuan terdiri dari:

A Kontrol

B $1 \mathrm{~N}, \mathrm{P}, \mathrm{K}(300-50-50 \mathrm{~kg} / \mathrm{ha})$ tanpa Nano Silika

C $1 \mathrm{~N}, \mathrm{P}, \mathrm{K}+1(2 \mathrm{~mL} / \mathrm{L})$ Nano Silika

D $1 \mathrm{~N}, \mathrm{P}, \mathrm{K}+1,5(3 \mathrm{~mL} / \mathrm{L})$ Nano Silika

E $1 \mathrm{~N}, \mathrm{P}, \mathrm{K}+2(4 \mathrm{~mL} / \mathrm{L})$ Nano Silika

F $3 / 4 \mathrm{~N}, \mathrm{P}, \mathrm{K}(225-37,5-37,5 \mathrm{~kg} / \mathrm{ha})$ $+1(2 \mathrm{~mL} / \mathrm{L})$ Nano Silika

G $\quad 3 / 4 \mathrm{~N}, \mathrm{P}, \mathrm{K}+1,5(3 \mathrm{~mL} / \mathrm{L})$ Nano Silika

$\mathrm{H} \quad 3 / 4 \mathrm{~N}, \mathrm{P}, \mathrm{K}+2$ (4 mL/L) Nano Silika 
Parameter utama dalam penelitian ini terdiri dari $\mathrm{N}$-total tanah, serapan $\mathrm{N}$ dan hasil padi hitam. Data hasil pengamatan dianalisis menggunakan SPSS versi 22 dengan uji F pada taraf galat 5\%. Pengujian dilanjutkan dengan uji lanjut jarak berganda Duncan pada taraf $5 \%$ untuk mengetahui pengaruh perlakuan terbaik.

\subsection{Tahapan Penelitian}

\subsubsection{Perlakuan Benih}

Sebelum ditanam benih padi hitam diberi perlakuan hot water treatment selama $1 \times 24$ jam (Akmal dan Nazarudin, 2016). Benih dimasukkan ke dalam wadah berisi air hangat $50^{\circ} \mathrm{C}$. Benih yang bernas akan ada didasar wadah, sehingga untuk penanaman digunakan benih yang berada didasar wadah tersebut.

\subsubsection{Persiapan Media Tanam dan Penanaman}

Tanah yang digunakan untuk media tanam dalam penelitian ini yaitu tanah Inceptisols asal Jatinangor. Media tanam berisi campuran tanah dan kompos dengan total 10 kg. Polybag diisi hingga $3 / 4$ bagian campuran tanah dan kompos, kemudian diberi lubang tanam dengan kedalaman 1-3 cm dari permukaan. Setiap lubang tanam diisi dengan 3-4 benih, setelah itu benih ditutup kembali dengan tanah (Akmal dan Nazarudin, 2016). Padi hitam ditanam dengan menggunakan polybag, dengan jarak tanam $25 \times 25 \mathrm{~cm}$.

\subsubsection{Pemupukan}

Pemberian kompos dilakukan dua minggu sebelum penanaman sebagai pupuk dasar sebanyak $74 \mathrm{~g} /$ rumpun atau 10 ton/ha. Pemupukan anorganik dilakukan sesuai dengan masing-masing perlakuan yang sudah ditentukan. Pemupukan SP-36 dan KCl dilakukan satu kali pada saat tanaman berumur 21 hari setelah tanam (HST) sedangkan pemupukan Urea dilakukan sebanyak tiga kali yaitu pada 21, 35, dan 56 HST.
Pemupukan nano silika pertama dilakukan sebagai perlakuan pada saat perendaman, kemudian dilakukan dengan penyemprotan pada permukaan daun pada tanaman berumur 35 HST dengan konsentasi 2 $\mathrm{mL} / \mathrm{L}, 3 \mathrm{~mL} / \mathrm{L}$ dan $4 \mathrm{~mL} / \mathrm{L}$ (sesuai perlakuan), pemberian selanjutnya pada fase bunting yaitu umur 56 HST dan umur 70 HST.

\subsubsection{Pemeliharaan dan Pengamatan}

Kegiatan pemeliharaan tanaman padi gogo hitam meliputi penjarangan, pengairan, penyiangan, serta pengendalian hama dan penyakit (Akmal dan Nazarudin, 2016). Penjarangan dilakukan satu minggu setelah tanam, yakni memilih satu tanaman untuk ditumbuhkan. Perlakuan pengairan dilakukan setiap pagi hari sebanyak $500 \mathrm{ml}$ agar tanaman mendapat air yang cukup dalam mengimbangi kehilangan air akibat dari transpirasi dan evaporasi.

Penyiangan dilakukan manual yaitu dengan mencabut gulma yang tumbuh disekitar tanaman padi. Pengendalian hama dan penyakit dapat dilakukan secara manual yaitu mengambil hama tersebut secara langsung atau memotong bagian tanaman yang terkena penyakit.

Upaya pengendalian secara organik menggunakan pestisida nabati daun kirinyuh (Chromolaena odorata L.) dengan dosis $2 \mathrm{~L} / \mathrm{ha}$. Variabel pengamatan meliputi tinggi tanaman padi dan jumlah anakan yang dilakukan setiap dua minggu sekali yaitu pada $3,5,7,9$, dan 11 MST.

\subsubsection{Pengambilan Sampel Tanah dan Tanaman}

Pengambilan sampel tanaman dilakukan pada fase vegetatif maksimum yaitu 77 HST dengan ditandai munculnya malai. Sampel tanaman diambil dengan cara memotong seluruh brangkasan tanaman padi, kemudian dihaluskan untuk dianalisis. Sampel tanah diambil sebanyak $500 \mathrm{~g}$ dari setiap ember, kemudian dikeringanginkan, dihomogenkan, 
serta dihaluskan. Setelah halus, sampel tanah kemudian disaring dengan diameter ayakan 0,5 $\mathrm{mm}$ dan dianalisis lebih lanjut di Laboratorium Kimia Tanah dan Nutrisi Tanaman sesuai dengan parameter yang diuji yaitu N-total dan serapan $\mathrm{N}$.

\subsubsection{Pemanenan}

Pemanenan dilakukan pada saat tanaman padi berumur 130 HST dengan ciri-ciri malainya sebagian besar telah menguning (95\%), tanaman sudah mulai rebah dan gabah mengeras. Proses pemanenan dilakukan dengan memotong bagian bawah tanaman padi menggunakan sabit bergerigi. Proses selanjutnya dilakukan perontokkan hasil gabah kering panen kemudian ditimbang, sedangkan untuk pengukuran hasil gabah kering giling dilakukan penjemuran terlebih dahulu. Penjemuran dilakukan dengan panas matahari selama tiga hari.

\section{HASIL DAN PEMBAHASAN}

\subsection{N-total Tanah}

Hasil analisis terhadap $\mathrm{N}$-total pada tanah (Tabel 1) menunjukkan bahwa N-total tanah berada pada kisaran nilai 0,12 - 0,19\%. Hasil analisis statistik menunjukkan bahwa $\mathrm{N}$-total pada semua perlakuan tidak berbeda nyata.

Tabel 1 Pengaruh Pupuk N, P, K dan Pupuk Nano Silika terhadap N-total Tanah

\begin{tabular}{clc}
\hline Kode & \multicolumn{1}{c}{ Perlakuan } & $\begin{array}{c}\text { N-total } \\
(\%)\end{array}$ \\
\hline A & Kontrol & 0,12 \\
B & $1 \mathrm{~N}, \mathrm{P}, \mathrm{K}$ tanpa Nano Silika & 0,19 \\
C & $1 \mathrm{~N}, \mathrm{P}, \mathrm{K}+1$ Nano Silika & 0,16 \\
D & $1 \mathrm{~N}, \mathrm{P}, \mathrm{K}+1$ 1 12 Nano Silika & 0,18 \\
E & $1 \mathrm{~N}, \mathrm{P}, \mathrm{K}+2$ Nano Silika & 0,13 \\
F & $3 / 4 \mathrm{~N}, \mathrm{P}, \mathrm{K}+1$ Nano Silika & 0,15 \\
G & $3 / 4 \mathrm{~N}, \mathrm{P}, \mathrm{K}+11 \mathrm{1} / 2$ Nano Silika & 0,16 \\
H & $3 / 4 \mathrm{~N}, \mathrm{P}, \mathrm{K}+2$ Nano Silika & 0,14 \\
\hline
\end{tabular}

Keterangan: Hasil uji F pada taraf 5\% non significant, sehingga tidak diakukan dilanjutkan uji lanjut jarak berganda Duncan.

Kandungan $\mathrm{N}$ total dalam tanah yang rendah menunjukkan efisiensi $\mathrm{N}$ yang rendah dalam tanah. Selain diserap oleh tanaman Nitrogen akan hilang pada proses denitrifikasi, volatilisasi dan tercuci oleh aliran permukaan (Wijaya, 2008). Tanaman dapat mengambil $\mathrm{N}$ sebagai $\mathrm{NO}_{3}{ }^{-}$dan $\mathrm{NH}_{4}{ }^{+}$. $\mathrm{NO}_{3}$ memiliki muatan negatif sehingga bergerak bebas melalui tanah yang menyebabkan mobilitasnya relatif tinggi dan rentan tercuci tanpa mengalami pertukaran (Mindari, et al., 2017).

\subsection{Serapan Nitrogen}

Hasil analisis terhadap serapan $\mathrm{N}$ (Tabel 2) menunjukkan bahwa perlakuan kombinasi pupuk memberikan pengaruh yang berbeda nyata, walaupun hal ini tidak terjadi antar perlakuan. Serapan N tanaman paling rendah terdapat pada perlakuan A (kontrol) karena tidak diberikan pemupukan, sedangkan serapan $\mathrm{N}$ tertinggi terjadi pada perlakuan $\mathrm{C}$ (1 dosis N, P, K dan 1 dosis nano silika). Perlakuan A (kontrol) berbeda nyata dengan perlakuan $\mathrm{F}$ ( $3 / 4$ N, P, K + 1 Nano Silika).

Tabel 2 Pengaruh Pupuk N, P, K dan Pupuk Nano Silika terhadap Serapan N Tanaman Padi Hitam

\begin{tabular}{|c|c|c|}
\hline Kode & Perlakuan & $\begin{array}{c}\text { Serapan N } \\
(\%)\end{array}$ \\
\hline A & Kontrol & $3,38 \mathrm{a}$ \\
\hline B & 1 N, P, K tanpa Nano Silika & $13,83 \mathrm{bcd}$ \\
\hline $\mathrm{C}$ & $1 \mathrm{~N}, \mathrm{P}, \mathrm{K}+1$ Nano Silika & $17,00 \mathrm{~d}$ \\
\hline $\mathrm{D}$ & $1 \mathrm{~N}, \mathrm{P}, \mathrm{K}+1,5$ Nano Silika & $15,55 \mathrm{~cd}$ \\
\hline E & 1 N, P, K + 2 Nano Silika & $14,72 \mathrm{~cd}$ \\
\hline $\mathrm{F}$ & $3 / 4 \mathrm{~N}, \mathrm{P}, \mathrm{K}+1$ Nano Silika & $10,61 \mathrm{~b}$ \\
\hline G & $3 / 4 \mathrm{~N}, \mathrm{P}, \mathrm{K}+1,5 \mathrm{Nano}$ Silika & $13,10 \mathrm{bc}$ \\
\hline $\mathrm{H}$ & 3/4 N, P, K + 2 Nano Silika & $11,80 \mathrm{bc}$ \\
\hline \multicolumn{3}{|c|}{$\begin{array}{l}\text { Keterangan: Nilai yang diikuti oleh huruf yang sama } \\
\text { tidak menunjukkan adanya perbedaan } \\
\text { yang nyata berdasarkan Uji Jarak } \\
\text { Berganda Duncan } 5 \% \text {. }\end{array}$} \\
\hline
\end{tabular}

Serapan $\mathrm{N}$ tertinggi terjadi pada perlakuan $\mathrm{C}$ ( 1 dosis $\mathrm{N}, \mathrm{P}, \mathrm{K}$ dan 1 dosis nano silika) dipengaruhi oleh pemupukan silika yang dapat meningkatkan stabilitas membran sel akar (Kristanto, 2018). Kestabilan membran sel akar dapat mencegah terjadinya kerusakan akar akibat adanya cekaman air pada tanaman padi gogo yang menjadi 
penyebab penurunan jumlah unsur hara yang diserap tanaman. Hal ini sejalan dengan Makarim dkk (2007) menyatakan bahwa unsur silika menyebabkan perakaran tanaman lebih kuat, intensif dalam penyerapan unsur hara.

\subsection{Hasil Panen}

Hasil bobot gabah kering panen dan gabah kering giling pada perlakuan $\mathrm{C}$ memiliki hasil bobot tertinggi dan sangat berbeda nyata dengan perlakuan lain. Bobot gabah kering panen (GKP) pada perlakuan C sebesar 81,7 $\mathrm{g} /$ rumpun dan bobot gabah kering giling sebesar 77,8 g /rumpun (Tabel 3). Hal ini selaras dengan nilai serapan $\mathrm{N}$ tertinggi yang juga terdapat pada perlakuan $\mathrm{C}$.

Tabel 3 Pengaruh pupuk N, P, K dan pupuk nano silika terhadap bobot gabah kering panen (GKP) dan gabah kering giling (GKG) tanaman padi hitam

\begin{tabular}{|c|c|c|}
\hline \multirow[b]{2}{*}{ Perlakuan } & GKP & GKG \\
\hline & \multicolumn{2}{|c|}{ (Kg/rumpun) } \\
\hline A Kontrol & $13,3 \mathrm{a}$ & $7,7 \mathrm{a}$ \\
\hline B $1 \mathrm{~N}, \mathrm{P}, \mathrm{K}$ tanpa Nano Sili & $34,2 \mathrm{~b}$ & $31,9 \mathrm{~b}$ \\
\hline C $1 \mathrm{~N}, \mathrm{P}, \mathrm{K}+$ & $81,7 \mathrm{~d}$ & $77,8 \mathrm{e}$ \\
\hline D $1 \mathrm{~N}, \mathrm{P}, \mathrm{K}+$ & $57,4 \mathrm{c}$ & $48,6 \mathrm{~cd}$ \\
\hline E $1 \mathrm{~N}, \mathrm{P}, \mathrm{K}+2$ Nano Silika & $56,3 \mathrm{c}$ & $46,8 \mathrm{c}$ \\
\hline F $3 / 4 \mathrm{~N}, \mathrm{P}, \mathrm{K}+1$ Nano Silika & $57,9 \mathrm{c}$ & $50,7 \mathrm{~cd}$ \\
\hline G 3/4 N, P, K + 1,5Nano Silika & $66,7 \mathrm{c}$ & $63,3 \mathrm{~d}$ \\
\hline $\mathrm{H}$ 3/4 N, P, K + 2 Nano Silika & $59,4 \mathrm{c}$ & $52,1 \mathrm{~cd}$ \\
\hline
\end{tabular}

Keterangan: Nilai yang diikuti oleh huruf yang sama tidak menunjukkan adanya perbedaan yang nyata berdasarkan Uji Jarak Berganda Duncan 5\%.
Suplai kecukupan nutrisi seperti N pada akhir musim tanam akan terakumulasi dalam biji lebih banyak oleh karena itu aplikasi nutrisi pada akhir musim tanam dapat meningkatkan kualitas biji dan hasil. Menurut Soplanit dan Nurkhulay (2012), bahwa penyediaan N yang cukup pada fase generatif sangat penting juga dalam memperlambat proses penuaan daun mempertahankan fotosintesis selama fase pengisian gabah dan peningkatan protein dalam gabah. Proses fotosintesis dipengaruhi oleh intensitas cahaya matahari yang diterima oleh tanaman.

Berdasarkan hasil pengamatan data iklim, kondisi suhu dan intensitas cahaya matahari belum mencapai suhu optimum untuk pertanaman padi yang berkisar antara $25-30{ }^{\circ} \mathrm{C}$ selama fase generatif (Kushwaha, 2016). Kekurangan radiasi matahari dan suhu yang tidak optium menjadi salah satu cekaman abiotik bagi tanaman padi hitam. Silika dengan ukuran nano dapat mengurangi transpirasi yang menyebabkan tanaman lebih rentan terhadap cekaman kekeringan, suhu, dan kelembaban (Al-Khuzai dan Al-Juthery, 2020).

Hasil GKP dan GKG padi hitam berkolerasi dengan jumlah anakan pada tanaman. Berdasarkan hasil pengamatan perlakuan C (1 N, P, K + 1 Nano Silika) memiliki rata-rata jumlah anakan paling banyak yaitu 46,5 anakan pada fase vegetatif maksimum (Gambar 1).

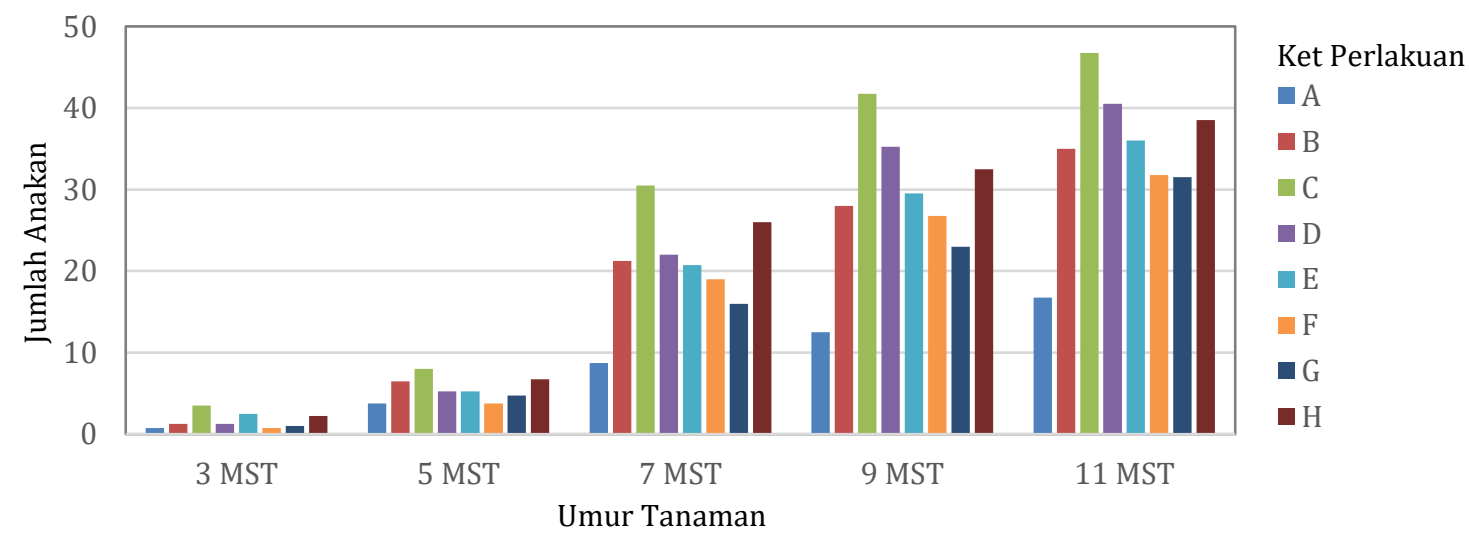

Gambar 1 Grafik Rata-rata Jumlah Anakan Padi Hitam pada 3, 5, 7, 9, 11 MST 


\section{KESIMPULAN}

Aplikasi pupuk N, P, K dan Pupuk Nano Silika berpengaruh nyata dalam meningkatkan serapan $\mathrm{N}$ dan hasil padi hitam (Oryza sativa L. indica) pada Inceptisols. Kombinasi dosis $1 \mathrm{~N}$, P, K (Urea $300 \mathrm{~kg} / \mathrm{ha}$, SP-36, $50 \mathrm{~kg} / \mathrm{ha}$, dan $\mathrm{KCl}$ $50 \mathrm{~kg} / \mathrm{ha}$ ) + 1 Nano Silika (2 mL/L) memberikan hasil tertinggi terhadap hasil Gabah Kering Giling sebanyak 77,8 g/ rumpun dan memberikan peningkatan hasil sebesar $79 \%$ dibandingkan dengan kontrol sebanyak 7,7 g/rumpun.

\section{DAFTAR PUSTAKA}

Al-Khuzai, A.H.G., and H.W.A. Al-Juthery. 2020. Effect of DAP fertilizer source and nano fertilizers (silicon and complete) spray on some growth and yield indicators of rice (Oryza sativa L. cv. Anber 33). IOP Conference Series: Earth and Environmental Science 553 (2020).

Amalya, N., A. Yuniarti, A. Setiawan, and Y. Machfud. 2020. The effect of N, P, K Fertilizer and Nano Silica Fertilizer to Total N Content, N Uptake, and Black Rice Yield (Oryza sativa L. Indica) on Inceptisols from Jatinangor. Journal of Plant Science. 8(2): 185-188.

Amrullah, S., D. Sugianta, dan A. Junaedi 2014. Peningkatan produktivitas tanaman padi (Oryza sativa L.) melalui pemberian nano silika. Jurnal Pangan. 23(1): 17-32.

Akmal dan Nazarudin. 2016. Petunjuk Teknis Budidaya Padi Gogo di Lahan Kering. Balai Pengkajian Teknologi Pertanian Sumatera Utara. Medan.

Dewi, T. K., T. Nurmala, Ruminta, M. Djali, dan D.M. Margana. 2017. Eksplorasi padi hitam (Oryza sativa L.) Jawa Barat. Prosiding Seminar Nasional PERIPI. Bogor, 3 oktober 2017. Hlm 29-37

Greger, M., T. Landberg \& M. Vaculík. 2018. Silicon influences soil availability and accumulation of mineral nutrients in various plant species. Plants. 7(2): 41.
Hayati, O. D. P., E. Prohastanti, E. D. Hastuti., 2019. Kombinasi pupuk nanosilika dan NPK untuk peningkatan pertumbuhan tanaman jagung (Zea mays L.) var pioneer 21. Jurnal Biologi Papua. 11(2): 94-102.

Kristanto, B.A. 2018. Aplikasi silika untuk pengelolaan kesuburan tanah dan peningkatan produksi padi secara berkelanjutan. Prosiding Seminar Nasional Pascasarjana Universitas Sebelas Maret (UNS) "Optimalisasi Potensi Lingkungan untuk Mewujudkan Ketahanan dan Keamanan Pangan". Surakarta 15 Agustus 2018.

Kushwaha, U.K.S. 2016. Black Rice: Research, History, and Development. Nepal Agricultural Research suardiCouncul. Nepal

Makarim, A.K., E. Suhartatik, dan A. Kartohardjono. 2007. Silikon: hara penting pada sistem produksi padi. Iptek Tanaman Pangan. 2(2): 195 204.

Marzuki, Murniati, dan Ardian. 2014. Pengaruh jarak tanam dan dosis pupuk terhadap pertumbuhan dan produksi padi sawah (Oryza sativa L.) dengan metode SRI. Jurnal Online Mahasiswa Fakultas Pertanian. 1(1): 1 - 12 .

Mindari, W., B. Widjajani, dan Priyadarsini. 2017. Kesuburan Tanah dan Pupuk. Gosyen Publishing. Yogyakarta

Suardi, D., dan Ridwan. 2009. Beras hitam, pangan berkhasiat yang belum populer. Warta Penelitian dan Pengembangan Pertanian. 31 (2): 910.

Subiksa, I. G. M. 2018. Pengaruh pupuk silika terhadap pertumbuhan dan hasil tanaman padi sawah pada Inceptisols. Jurnal Tanah dan Iklim, 42(2), 153-160.

Sudarwati, S. 2018. Prospek pengembangan beras hitam di Kabupaten Brebes, Jawa Tengah. Semarang. Prosiding Seminar Nasional Kesiapan Sumber Daya Pertanian dan Inovasi Spesifik Lokasi Memasuki Era Industri 4.0. 
Balai Pengkajian Teknologi Pertanian Jawa Tengah. Hal: 508 - 512.

Soplanit, R. dan S. Nurkhulay. 2012. Pengaruh pengelolaan hara NPK terhadap ketersediaan $\mathrm{N}$ dan hasil tanaman padi sawah (Oryza sativa L.) di Desa Waelo Kecamatan Waeapo Kabupaten Buru. Journal Agrologia, 1(1): 81-90.

Wijaya, K. A. 2008. Nutrisi Tanaman, sebagai Penentu Kualitas Hasil dan Resistensi Alami Tanaman. Prestasi Pustaka Publisher. Jakarta. 